\title{
VIRGINIA WOOLF AND PHOTOGRAPHY ${ }^{1}$
}

\author{
Maggie Humm
}

\begin{abstract}
From 2000, criticism on Woolf and the visual has quadrupled in volume. The research work about a photographic Woolf - which include other photographers' interaction with Woolf such as Gisèle Freund or my own analysis of Woolf and Bell's personal photo albums - shows how these newer issues of Woolf and photography are now absolutely central in any consideration of Virginia Woolf studies, gaining a noticeable importance when we consider the interdisciplinary issue of photography and gender.
\end{abstract}

KeYwORDS

Virginia Woolf; photography; Visual Culture; Cultural Studies

\begin{abstract}
RESUMo
A partir do ano 2000, o volume da análise crítica sobre Woolf e a sua relação com o visual tem quadruplicado. O trabalho de pesquisa sobre uma Woolf fotográfica - que inclui a interação de outros fotógrafos com Woolf, como Gisèle Freund, ou a minha própria análise dos álbuns de fotos pessoais de Woolf e Bell - mostra como estas mais recentes questões de Woolf e da fotografia são agora um tema absolutamente central em qualquer análise dos estudos de Virginia Woolf, adquirindo uma importância notória se considerarmos o aspeto interdisciplinar da fotografia e do género.
\end{abstract}

Palavras-chave

Virginia Woolf; fotografia; Cultura Visual; Estudos Culturais

From the age of fifteen, photographs framed Woolf's world. Virginia Woolf wrote about photography in her diaries, letters and essays, and used photographic terms descriptively in her fiction. Before her marriage, and then together with Leonard, Woolf took, developed and preserved over one thousand photographs in albums. Photography was a continuous part of the Woolfs' lives even if their photographic albums do not tell a coherent life story (Humm, 2005).

She skilfully transformed friends and moments into artful tableaux and she was surrounded by female friends and family who were also energetic photographers such as Lady Ottoline Morrell, Vita Sackville-West and the artist Dora Carrington. At fifteen she

\footnotetext{
'This article, which summarizes my work on Woolf and photography (Humm, 2003, 2005), is the written version and the final edition of a lecture I prepared for the Société d'Etudes Woolfienne's international conference "Virginia Woolf and Images: Becoming Photographic" (2016), held in the University of Toulouse, in 2016: http://sait-france.org/evenements/ virginia-woolf-and-images-becoming-photographic/
} 
used a Frena camera, as her letters to Thoby Stephen and George Duckworth reveal. The Frena, a box-form magazine camera launched in 1896, had a fixed focus lens and eccentric magazine handle requiring a dedicated camera operator. Woolf may be holding her Frena in Vanessa Bell's photograph of Virginia and Julian taken at Blean in 1910 which is in Snapshots (Humm, 2005, p. 87).

The essence of photographs lies in the appeal of the experience or the event portrayed to a viewer. Woolf, like her sister and her great aunt, the photographer Julia Cameron, frequently invited friends to share her reflections. The letters and diaries describe a constant exchange of photographs, in which photographs become a meeting-place, a conversation, aide-mémoires, and sometimes mechanisms of survival and enticement. At age 16, photographs were "the best present I can think of." (Nicolson \& Trautmann, 1975, p. 18). Virginia was happy to send a photograph of herself to her friend Emma Vaughan even if "it is somewhat like an ancient beast of my acquaintance" (Nicolson \& Trautmann, 1975, p. 29). Visiting the professional photographer Beresford for the now famous sitting was "an entertainment" (Nicolson \& Trautmann, 1975, p. 78).

By the age of 21, friends photographs were like erotic emblems. "I have Marny's [Madge Vaughan] photograph on my shelf, like a madonna to which I pray. She makes my room refined, as lavender in my drawers - (!!)" (Nicolson \& Trautmann, 1975, p. 88). The first volume of Woolf's collected letters ends appropriately with Virginia sending her photograph to Leonard. "Dýou like this photograph? - rather too noble, I think. Here's another" (Nicolson \& Trautmann, 1975, p. 497). Woolf invited friends to share their lives with her through photographs. She liked "very much" to have baby photographs "he's an interesting little boy" [Katherine Arnold-Forster's son Mark] (Nicolson \& Trautmann, 1975, p. 495). Barbara Bagenal's photograph of herself and her son "exactly like his father" is "stuck in my book" and an exchange impossible because "mine all got the foggy dew this summer" (Nicolson \& Trautmann, 1975, p. 6). The Bagenal photographs are mounted on card in Woolf's Monk's House Album 2 visually replicating the way Woolf carefully conserved her friendships. After their deaths, photographs of friends were important memento mori. Wanting to send Jacques Raverat, the French painter, "a picture of me done for a vulgar paper called Vogue", after his death in 1925 she needed photographs to continue her mental conversations, and from Gwen Raverat, Woolf desperately wanted "a snapshot or any photograph of him? I go on making things up to tell him" (Nicolson \& Trautmann, 1977, p. 130, pp. 172-173). In the Vogue photograph Virginia is wearing her mother's dress. Woolf believed that photographs could help her to survive those identity destroying moments of her own life - her incoherent illnesses. For example, writing to Margaret Llewelyn Davies in 1915, Woolf "wanted to say that all through that terrible time" [a week's attack of apparent insanity] "I thought of you, and wanted to look at a picture of you, but was afraid to ask!" (Nicolson \& Trautmann, 1976, p. 60). Photographs of friends were crucial to Woolf's own sense of identity. Friends' photographs often provide solidly visible autobiographical evidence when feelings of loss of identity become overwhelming.

Mutual image making would also create relationships. Woolf used photographs to entice Vita Sackville-West. Writing to "Mrs Nicolson" in 1923, Woolf asked Vita to visit in 
order "to look at my great aunt's photographs of Tennyson and other people" (Nicolson \& Trautmann, 1977, p. 4). By 1926, more desperately, Woolf was writing to Vita's mother, Lady Sackville, for the name of Vita's passport photographer so "that I may write to him myself" for a copy of the photograph (Nicolson \& Trautmann, 1977, p. 246). Virginia took Vita to London to be photographed for Orlando and used the excuse of further illustrations to make additional visits to Knole and more photography sessions. "You'll lunch here at one sharp on Monday won't you: bringing your curls and clothes. Nessa [Vanessa Bell] wants to photograph you at 2" (Nicolson \& Trautmann, 1977, p. 435). The photograph appears in Orlando as Orlando about the year 1840.

Writing to her friend Ethel Smyth in 1940 Woolf compared her own subjective feelings to a photographic process. "How then do I transfer these images to my sensitive paper brain? Because I have a heart. Yes, and it is the heart that makes the paper take, as they say" (Nicolson \& Trautmann, 1980, p. 393). In particular, Woolf needed photographs in order to write. For example, she asked Vita, in 1931, for "a photograph of Henry", [Harold Nicolson's cocker spaniel], "I ask for a special reason, connected with a little escapade" which became Woolf's book Flush (Nicolson \& Trautmann, 1978, p. 380). The ironic photographs in Flush and Three Guineas, the loving construction of Vita and Angelica's photographs in Orlando parallel the multiple references to photographs in Woolf's fiction. For example, in Night and Day Woolf judges characters by the photographs they display in their houses. In short, photographs may be "only an eye" but enabled Woolf to see more clearly.

\section{WOOLF STUDIES ON PHOTOGRAPHY}

That Woolf's imagination was shaped by photography became a key focus in the 1990s, undoubtedly triggered by developments in literary criticism and cultural studies in the decade, often couched as the turn to the visual. Critics argued that Woolf used photography to de-stabilise preconceived ideas of biography and that Woolf's textual representations mirrored photography (Wussow, 1994; Neverow, 1999). Woolf's own photographic practice became the focus of my work (Humm, 1999). One key volume was Diane F. Gillespie and Leslie K. Hankins edited collection Virginia Woolf and the Arts which brought together much of the now extensive new work on Woolf and the visual, and contained Gillespie's richly detailed essay on Woolf and photography (Gillespie \& Hankins, 1985).

From 2000, criticism on Woolf and the visual has quadrupled in volume, and is even more wide-ranging and far-reaching, matching a new attention to Bloomsbury art in public galleries. Attention to a photographic Woolf broadened to include other photographers' interaction with Woolf such as Gisèle Freund, and Woolf's scrapbooks (Luckhurst, 2001; Pawlowski, 2010). Further archival research included my own analysis of Woolf and Bell's personal photo albums and of cinema (Humm, 2003; Humm, 2005). The work still in progress shows how these newer issues of Woolf and photography are now absolutely central in any consideration of Woolf studies, confirmed by events such as the International Société d'Etudes Woolfienne's conference Virginia Woolf and Images: 
Becoming Photographic (2016) (Dickey, 2010; Cassigneul, 2014), which was the starting point for this article. On the other hand, the issue of Woolf and photography becomes also a reference in the interdisciplinary field of visual culture, assuming an important role in the consideration of the feminist appropriations of the photographic device.

\section{WOOLF'S ESSAYS}

Woolf wrote many essays which touch on photography often paying attention to photography even in those essays not directly about visual topics. For example, Gold and Iron begins with a knowledgeable description of how to develop photographs. Woolf's voice is always multi-tonal even in the brief "I was given the opportunity..." to see FrieseGreene's "new colour film process" where she shows a pointed understanding of colourism in cinema (Mcneillie, 1986, p. 403). In Julia Margaret Cameron, Woolf describes her great-aunt's life and career. Woolf's own continual photographic practice informs her understanding of how Cameron's photography engenders and expresses a "sensibility" (Mcneillie, 1998, p. 381). Cameron's use of dark, amorphous backgrounds and sfumato, or blurred outlines, matches Woolf's refusal to create two-dimensional characters.

Although not a cineaste Woolf makes perceptive comments about the new art, and Woolf's The Cinema is the first British essay about avant-garde film (and Woolf saw many films, including Storm Over Asia, Le Million, and Wuthering Heights). The Cinema, ostensibly about The Cabinet of Dr Caligari, discusses a range of films, including newsreels and Anna Karenina. The essay reveals Woolf's knowledge of cinematic processes - of close-ups seeing "the very quivers" of a character's lips, as well as the use of objects "pebbles on a beach" to suggest emotions (Mcneillie, 1998, p. 351). Woolf points to the unconscious optics of cinema, and judges the art of cinema to lie, not in its subject matter, but in film processes, especially film's use of constitutive absence "we behold them [people and objects] as they are when we are not there", and how film connects with spectators' unconscious thoughts and memories (Mcneillie, 1998, p. 349). Later, Woolf adopts the perspective of a modernist photographer in The House of Commons, "we look down upon some of the glossiest top hats" presaging her more feminist viewpoints of Three Guineas, and its visual/political images of men's clothing (Clarke, 2009, p. 325). Modern technologies enable Woolf to new modernist perceptions.

\section{WOOLF, WRITING AND PHOTOGRAPHY}

Virginia Woolf is one of the foremost visual writers of the $20^{\text {th }}$ century. She frequently uses a vocabulary drawn from photography, for example, in To the Lighthouse and in her short stories Blue and Green, and Monday or Tuesday. Several of her books contain illustrations: Flush, Orlando, Roger Fry: A Biography and Three Guineas. The Woolf's Hogarth Press taught Woolf the graphic arts of formatting and spatial form, with Woolf herself type-setting thirty-four books. And the Woolfs published books about cinema, for example, Eric White's Walking Shadows (1931). First, I will examine analogies: how scenes 
and descriptions in her writing often match her own domestic photography and that of her family. Second I want to examine adoptions by Woolf of the languages and methods of photography. This includes her use of photographic tropes for example in Flush; but, more importantly, the way in which her knowledge of photography encouraged Woolf to find new ways of representing political arguments for example, in Three Guineas.

\section{Analogies}

One of the things I discovered when researching my book Snapshots of Bloomsbury is that there are close parallels between details in the domestic photographs taken by Virginia Woolf and photos taken of her, and descriptive details in Woolf's writing. Often Woolf seems to be describing not an actual memory but as if describing a photograph in front of her in the albums. For example, Woolf's descriptions, in her autobiographical Reminiscences of her sister Vanessa's "honesty", "clinging to truth too tenaciously" which Woolf examples by a cricketing reference - "she played cricket better for the same reasons, with her straightforward stroke" match a photograph taken at Talland House their childhood summer home (Woolf, 1985, p. 31; Humm, 2005, p. 53). The famous opening of Woolf's autobiography A Sketch of the Past: "I begin: the first memory. This was of red and purple flowers on a black ground - my mother's dress; and she was sitting either in a train or in an omnibus, and I was on her lap" matches plate $36 \mathrm{f}$ in Leslie Stephen's photo album which Woolf owned at the time she wrote the autobiography (Woolf, 1985, p. 64). The photograph was, of course, black and white and hence in addition to the overall scene Woolf emphasises the "black ground" of her mother's dress. The photograph is the first photograph taken of Woolf and hence becomes the first memory.

Crucially for Woolf's subsequent photography and writing, in 1892 her sister Vanessa took a key photograph of Virginia together with their mother Julia and father sitting reading at Talland House (Humm, 2005, p. 46). All three sisters' albums, Virginia's, Vanessa's and their half-sister Stella's, contain this 1892 photograph in which Virginia gazes at Vanessa as camera operator as if sharing a "primal scene". Woolf's father also memorialises the photograph in his Mausoleum Book written about the dead Julia, and includes it in his photo album (although dating the photograph 1893). And the scene is recreated in To the Lighthouse when Mr. and Mrs. Ramsay read together "here he looked at her reading. She looked very peaceful, reading" and Mrs. Ramsay a sentence or so later is reading of roses "laying hands on one flower and then another" which resemble the details of flowers at the rear of the photograph (Woolf, 1992, pp. 162-163).

Woolf's essays and non-fiction texts often use a dialogic form in order to break with straightforward causality and to bring in the reader. Melba Cuddy-Keane has argued that this use of a dialogic form "constitutes Woolf's greatest separation" from conventional academia in the 1920s (Cuddy-Keane, 2003, p. 79). There are immediate analogies between Woolf's technique in prose and the photographs that the Woolfs were taking at this time. The Woolfs preference for paired self-portraits of themselves and their friends constitute a dialogic and repetitive visual autobiography. 
These repetitive paired sequences go beyond the conventions of candid or instant photography. In their use of repetition the photographs encourage dialogue between the sitters and between husband and wife as camera operators (Humm, 2005, p. 127). The constant pairing of husband and wife and of friends over decades is a dialogic practice, for example the album's placing of photographs of John Maynard Keynes and his wife Lydia also exaggerate the quality of coupledom (Humm, 2005, p. 132). They are double portraits in which each figure has great presence. These photographs displace the normal amateur gap between subject and photographer.

Similarly in Woolf's criticism, Woolf's frequently dialogues with the reader. The introduction to her Life As We Have Known It makes us active readers because the narrator apparently has great difficulty in describing scenes. She sees a woman "wearing something like a chain" (obviously a Mayoress) (Woolf \& Clarke, 2009, p. 226). Miss Kidd is wearing deep purple "the colour seemed somehow symbolical", the narrator seems not to know the suffragette colours, asking "what is the use of it all?" (Woolf \& Clarke, 2009, pp. 230-232).

Other uses of a dialogic form come in Woolf's interactions with her father Leslie Stephen's writings. For example, there are very close parallels between some of Woolf's essays and those of Stephen's Hours in a Library. About the writer de Quincey Stephen wrote "he is utterly incapable of concentration...the most diffuse of writers" (Stephen, 1874, p. 230). Woolf writes on de Quincey fifty years later "he was profusely and indiscriminately loquacious. Discursiveness - the disease" (Woolf \& Clarke, 2009, p. 455). Reading the essays of Stephen and Woolf together is like hearing two voices in dialogue, and too in disagreement particularly about women writers like George Eliot when Stephen praises Eliot's early agricultural scenes and Woolf argues "confine George Eliot to the agricultural world" would "lose her true flavour" (Woolf \& Mcneillie, 1998, p. 177).

\section{Adoptions}

The most obvious adoptions Woolf makes in her writings are of photographic tropes. By the 1930 s a new language of modernism had emerged in response to developments in visual cultures including cinema and photographic technologies. Modernism's new visual vocabularies, shaped by photography's strategies of close-ups, unusual viewpoints and sharp tonal contrasts emerge in Virginia Woolf's The Waves - where light transforms objects. The new style was conspicuously urban. Subjects included tall skyscrapers, street scenes and everyday objects often shot with dramatic viewpoints and tonal contrasts. Modernist writing was part of a world in which ubiquitous photographic technologies shaped urban modernity into dramatic and multi-perspective images. It is not really surprising that Woolf would want to adopt these in her writings.

Yet this complex experience of visual technologies seems at odds with one of Virginia Woolf's most popular novels of the 1930s - Flush, a novel seemingly all about the sense of smell not sight. Flush is a novel about the dog Flush belonging to the $19^{\text {th }}$ century poet Elizabeth Barrett Browning and their lives together told from the point of 
view of the dog. But it is through reading a book like Flush, one apparently least open to visual interpretations, that the crucial impact of modernity's photography on Woolf can be seen.

The writing of Flush did begin and end with visual technologies. As noted, on 16 September 1931, Woolf wrote to Vita Sackville-West asking for a photograph, but it was another dog Pinka, given to Woolf by Vita, who eventually became Flush. Woolf first conceived of Flush as a visual figure. "Read the Browning love letters, and the figure of their dog made me laugh so I couldn't resist making him a Life" (Woolf, 1979, p. 161-162). In October 1933, following the huge success of Flush in Britain and America, Woolf was again excited by the visual possibilities of Flush. "It's possible that Flush is to be pictured" (Bell \& McNeillie, 1982, p. 186). The film was never made but the director Joseph Fiennes is to film Flush in 2017.

References to the visual appear throughout the novel. It is as if engaging in photography's representative techniques enables Woolf to figure and finish Flush as a series of connected visual objects. "I visualise this book now... as a series of great balloons...I can take liberties with the representational form" (Bell \& McNeillie, 1982, p. 142). In Florence, Flush witnesses street politics from above, the typical point of view of the modernist urban photographer. Under the Barrett Browning's balcony "a vast crowd was surging underneath...the people in the street - grave men, gay young women - were kissing each other and raising their babies to the people in the balconies" (Woolf, 1933, pp. 79-80). Photography had maximised panoramic and elevated urban vantage points of view by developing faster shutter exposure times.

Flush theorizes as much through his visual imagination as through his sense of smell. Flush's unremitting effort to visualise his surroundings through the photographic enables Woolf to create a humorous distancing. When Flush sees Elizabeth Barrett Browning's new baby he thinks: "it was a live animal. Independently of them all, without the street door being opened, out of herself in the room, alone, Mrs. Browning had become two people" (Woolf, 1933, p. 83). A photographic perception permits the humour. It is precisely because the photographic makes such continuous interventions in Flush that Flush, just as other of Woolf's work, is structured by adoptions of the visual.

A much more complex adoption of photography occurs in Woolf's Three Guineas. Virginia Woolf's Three Guineas, is about the giving of three guineas to those who can prevent war and demonstrates one major way in which photographs and visual memories can reveal a gendered subjectivity in the differing ways with which Woolf counters a masculine patriarchal world, as represented by published photographs: a general, heralds, university professors, a judge, and an Archbishop, with the feminine "affect" of the narrator's visual memories of photographs of fascist atrocities sent to British supporters during the Spanish Civil War by the Republican government, which are not reproduced in the text.

In my view it is the absent photographs that in a major way shape the narrative of Three Guineas. Three Guineas is structured by many references to "dead bodies and ruined houses" in which the narrator's differing looks trigger Woolf's political analysis of 
patriarchy. The absent photograph functions as a transactional act of memory between narrator and reader. Woolf achieves this by means of specific, visual details. In the absent photograph the ruined houses resemble a child's game of spillikins, a domestic game. The "certain" bodies are those of children, and the houses still retain "a bird-cage" itself often a compelling metaphor of Victorian women's private seclusions (Woolf, 1993, p. 125), Woolf subsequently abbreviates the detailed account into a single phrasal mnemonic occurring at further points in the text, for example "the photograph of ruined houses and dead bodies" (Woolf, 1993, p. 138), or "pictures of dead bodies and ruined houses" (Woolf, 1993, p. 154).

Each memory of the absent photographs builds on another enabling Woolf to envision more radical reforms for women. "Also consider these photographs: they are pictures of dead bodies and ruined houses. Surely in view of these questions and pictures you must consider very carefully before you begin to rebuild your college what is the aim of education (...) Now since history and biography - the only evidence available to an outsider - seem to prove that the old education," the narrator claims, breeds no "hatred of war", then the new college must be "an experimental college" (Woolf, 1993, p. 132133). Each memory of the absent image gives Woolf the strength to move forward into a more complex social agenda, by switching Woolf's vision from simply championing equal opportunities - because the masculine professional agenda only makes people "lose their senses" (Woolf, 1993, p. 197), to imagine new cultural and intellectual liberties in the Outsiders Society. Woolf's deep knowledge of photography - her constant photographic practice, photo album construction, and the continued experience of being photographed throughout her life - inspired her to choose photography as a generative medium in Three Guineas.

Other Woolf writings influenced by photography include The Years which is photographic in the way it rethinks the relationship between characters and space. "Kitty who had altered the focus of her eyes to suit the smallness of the Robson family, was taken by surprise." (Woolf, 2000, p. 60); Martin stands in front of St. Paul's cathedral. "He stood with his back pressed against the shop trying to get the whole of the Cathedral clear" (Woolf, 2000, p. 199).

\section{ConcLusion}

Woolf's attention to photography is a constant theme in her work. Her own photographs are transactional, containing exchanges and gestures going beyond what we normally find in family albums but synchronising with a period that had a renaissance of the literature of personality, just as Woolf in fiction frequently creates meaning through characters' gestures. To Woolf then, photographs are not transparent, unproblematic representations of the real. She uses them for her writings with adoptions and analogies, and her own photographs are forms of self-inquiry representing material, subjective and cultural identities as well as being, of course, snapshots of Bloomsbury. / 


\section{BIBLIOGRAPHIC REFERENCES}

Bell, A. O. \& McNeillie, A. (Ed.) (1982). The Diary of Virginia Woolf, Vol. Four, 1931-1935. New York: Harcourt Brace Jovanovich.

Cassigneul, A. (2014). Voir, observer, penser: Virginia Woolf et la photo-cinématographie. Doctoral Thesis, University Toulouse Jean Jaurés, Toulouse, France. Retrieved from http://www.theses.fr/2014TOU20048.

Clarke, S. (Ed.) (2009). The Essays of Virginia Woolf, Vol. Five, 1929-1932. London: The Hogarth Press.

Cuddy-Keane, M. (2003). Virginia Woolf, the Intellectual, and the Public Sphere. Cambridge: Cambridge University Press.

Dickey, C. (2010). Virginia Woolf and Photography. In M. Humm (Ed.) The Edinburgh Companion to Virginia Woolf and the Arts (pp. 375-391). Edinburgh: Edinburgh University Press.

Gillespie, D. F. \& Hankins, L. K. (Eds.) (1985). Virginia Woolf and the Arts. New York: Pace University Press.

Humm, M. (1999). Virginia Woolf's Photography, Virginia Woolf Bulletin, 1, 19-21.

Humm, M. (2003). Modernist Women and Visual Cultures: Virginia Woolf, Vanessa Bell, Photography and Cinema. New Brunswick, New Jersey: Rutgers University Press.

Humm, M. (2005). Snapshots of Bloomsbury: the Private Lives of Virginia Woolf and Vanessa Bell. New Brunswick, New Jersey: Rutgers University Press.

Luckhurst, N. (2001). Photoportraits: Gisèle Freund and Virginia Woolf. In J. Berman \& J. Goldman (Eds.), Virginia Woolf Out of Bounds (pp. 197-206). New York: Pace University Press.

Marcus, L. (2010). Virginia Woolf as Publisher and Editor: the Hogarth Press. In M. Humm (Ed.), The Edinburgh Companion to Virginia Woolf and the Arts (pp. 280-297). Edinburgh: Edinburgh University Press.

Mcneillie, A. (Ed.) (1986). The Essays of Virginia Woolf, Vol. Three, 1919-1924. New York: Harcourt Brace Jovanovich.

Mcneillie, A. (Ed.) (1998). The Essays of Virginia Woolf, Vol. Four, 1925-1928. London: The Hogarth Press.

Neverow, V. (1999). "Thinking Back Through Our Mothers": Thinking in Common Virginia Woolf's Photographic Imagination and the Community of Narrators in Jacob's Room, A Room of One's Own, and Three Guineas. In J. Mcvicker \& L. Davis (Eds), Virginia Woolf a Communities: Selected Papers from the Eighth Annual Conference on Virginia Woolf (pp. 65-90). New York: Pace University Press.

Nicolson, N. \& Trautmann, J. (Eds.) (1975). The Letters of Virginia Woolf: Vol. One, 1888-1912. New York: Harcourt Brace Jovanovich.

Nicolson, N. \& Trautmann, J. (Eds.) (1976). The Letters of Virginia Woolf: Vol. Two, 1912-1922. New York: Harcourt Brace Jovanovich.

Nicolson, N. \& Trautmann, J. (Eds.) (1977). The Letters of Virginia Woolf: Vol. Three, 1923-1928. New York: Harcourt Brace Jovanovich.

Nicolson, N. \& Trautmann, J. (Eds.) (1978). The Letters of Virginia Woolf: Vol. Four, 1929-1931. New York: Harcourt Brace Jovanovich.

Nicolson, N. \& Trautmann, J. (Eds.) (1979). The Letters of Virginia Woolf: Vol. Five, 1932-1935. New York: Harcourt Brace Jovanovich. 
Nicolson, N. \& Trautmann, J. (Eds.) (1980). The Letters of Virginia Woolf: Vol. Six, 1936-1941. New York: Harcourt Brace Jovanovich.

Pawlowski, M. (2010). Virginia Woolf and Scrapbooking, In M. Humm (Ed.), The Edinburgh Companion to Virginia Woolf and the Arts (pp. 298-213). Edinburgh: Edinburgh University Press.

Stephen, L. (1874). Hours in a Library. London: Smith Elder \& Co.

Woolf, V. (1933). Flush. London: Hogarth Press.

Woolf, V. (1985). Moments of Being. New York: Harcourt Brace Jovanovich.

Woolf, V. (1992). To the Lighthouse. Oxford: Oxford University Press.

Woolf, V. (1993). Three Guineas. Harmondsworth: Penguin.

Woolf, V. (2000). The Years. London: Vintage.

Wussow, H. (1994). Virginia Woolf and the Problematic Nature of the Photographic Image. Twentieth Century Literature, XLIL, 1-14.

\section{BiographicAL Note}

Maggie Humm is an Emeritus Professor of Cultural Studies in the The School of Arts and Digital Industries at the University of East London. She is the author of many books including Snapshots of Bloomsbury: The Private Lives of Virginia Woolf and Vanessa Bell (Tate Publishing \& Rutgers University Press, 2006) and Modernist Women and Visual Cultures: Virginia Woolf, Vanessa Bell, Photography and Cinema (Edinburgh University Press \& Rutgers University Press 2002).

E-mail:humm@uel.ac.uk; maggie@maggiehumm.net

The School of Arts and Digital Industries, University of East London, University Way, London, E16 2RD, United Kingdom

\section{* Submitted: 05-07-2017 \\ *Accepted: 30-09-2017}

